\section{СПИСОК ВИКОРИСТАНОЇ ЛІТЕРАТУРИ}

1. Закон України «Про освіту» від 05.09.2017 № 2145-VIII. URL: http://zakon2.rada.gov.ua/laws/ show/2145-19 (дата звернення: 20.10.2019).

2. Концепція Нової української школи. URL: http://mon.gov.ua/Новини 2016/12/05/konczepcziya. pdf (дата звернення: 20.10.2019).

3. Бех І.Д. Компетентнісний підхід у сучасній освіті / I.Д. Беx. URL: http//www.ipv.org.ua/component/article/ 8-beh /56-2012-09-04-22-32-01 html (дата звернення: 05.10.2019).

4. Василенко Н. В. Українська школа XXI століття: школа шкіл / Н. В. Василенко. - Х. : Вид. група «Основа», 2018. - 96 с. - (Бібліотека журналу «Управління школою»; Вип.6 (185)).

5. Гондюл І. Управління персоналом навчального закладу / І. Гондюл // Відкритий урок. - 2013. № 11. - C. $10-14$

6. Дичківська І. М. Інноваційні педагогічні технології: Навчальний посібник / І. М. Дичківська. - К. : Академвидав, 2004. - 352 с

7. Єльникова Г. В. Управлінська компетентність / Г. В. Сльникова. - К. : Ред. загальнопед. газ., 2005. $128 \mathrm{c}$.

8. Інноваційний менеджмент : навч. посібник / авт.. кол. : Л. І. Михайлова, О. І. Гуторов, С. Г. Турчіна, І. О. Шарко. - К. : Центр навчальної літератури, 2015. - Вид. 2-ге, доп. - 234 с.
9. Інноваційні пошуки в сучасній освіті / за ред. Л. І. Даниленко ; Центр. ін-т післядиплом. пед. освіти АПН України. - К. : Логос, 2005. - 220 с.

10. Калініна Л. Управління Новою українською школою. Порівняльна характеристика концептуальних змін / Л. Калініна // Директор школи. - 2017. Січень. - С.12-21.

11. Касьянова О. М. Контрольно-аналітична діяльність керівника навчального закладу / О. М. Касьянова. - Х. : Вид. група «Основа», 2014. - 192 с. (Серія «Абетка керівника»).

12. Литвин Л. Менеджмент освітніх інновацій: сутність та особливості впровадження / Л. Литвин, Р. Горбатюк // Соціально-економічні проблеми і держава. - 2013. - Вип. 1 (8). - С. 108-115. URL: http:// sepd.tntu.edu.ua/images/stories/pdf/2013/131lmtov.pdf (дата звернення: 05.10.2019).

13. Ляшенко О. І. На шляху до нової української школи: концептуальні засади і виклики / О. І. Ляшенко, Ю. І. Мальований // Педагогіка і психологія. 2017. - № 3. - C. 5-12.

14. Максименко С. Д. Лідерство як функція професійної психологічної компетентності особистості / С. Д. Максименко // Педагогіка і психологія: наук.-теорет. та інформ. вісн. НАПН України ; Нац. акад. пед. наук України. - Київ : Вид-во «Педагогічна преса», 2014. - № 3. - С. 28-33.

15. Нова українська школа: порадник для вчителя / за заг. ред. Н. М. Бібік. - К. : ТОВ «Видавничий дім «Плеяди», 2017. - 206 с.

Дата надходження до редакиії: 20.11.2019 p.

Оксана ЛЮТКО,

кандидат філософських наук, дочент, завідувач кафедри філософії, економіки та менеджменту освіти Рівненського ОІППО

\title{
ТЕОРЕТИКО-МЕТОДОЛОГІЧНІ ЗАСАДИ МОТИВАЦІЙНОГО МЕНЕДЖМЕНТУ В ОСВІТІ
}

У статті зроблено спробу критично проаналізувати наукові дослідження та публікаиії, де окреслено сутність поняття «мотиваційний менеджмент», а також представити його авторське формулювання. Визначено об 'єкт і предмет мотивачійного менеджменту, основні етапи його запровадження в закладі освіти.

Ключові слова: прочес управління людськими ресурсами, мотивачія діяльності педагогічних кадрів, мотиваційний менеджмент, засоби впливу на мотивацію, етапи запровадження мотиваційного менеджменту в закладі освіти.
В статье сделана попытка критически проанализировать научные исследования и публикации, где обозначена сущность понятия «мотивационный менеджмент», а также представить его авторские формулировки. Определень объект и предмет мотивационного менеджмента, основные этапы его внедрения в учебном заведении.

Ключевые слова: прочесс управления человеческими ресурсами, мотиваџия деятельности педагогических кадров, мотивационный менеджмент, способы влияния на мотивацию, этапь внедрения мотивационного менеджмента в учебном заведении. 
The peculiarity of the management of modern educational organizations is that it includes two components: the management of the educational process and the management of the people who participate in it. However, successful management of the first component is impossible without managing the staff of the educational institution. Therefore, the ability to prompt employees to achieve goals of the institution is one of the defining skills of the modern manager, which can be formed using motivational management.

The term "motivational management» is relatively new to Ukrainian science, although it has been used extensively in foreign scientific research since the mid1990 s. The authors interpret it as a set of tools that prompt employees to achieve the goals of the institution; management, in which the main priorities are given to motivation of creative, productive, initiative and professional activity of the person; as a system of action to activate another person's motives; as a human resource management process and etc. Motivational management is understood as a flexible, multilevel and multifaceted process of internal management of the activity of an educational institution, built on the compulsory consideration of the motivated professional or independent and collective behavior and common activity of all employees, due to the developed and committed team in achieving the goals of the institution, adherence to the value guidelines, formation and maintenance of motivational climate in the institution. The object of motivational management is to manage the process of formation the motivation of all employees of the educational institution to achieve a common goal. The subject of motivational management is the psychological patterns of forming the motivational sphere of employees, achieving their common goal and specific goals in their professional activity.

Key words: process of human resource management, motivation of pedagogical staff activity, needs, values, theory of motivation, motivational management, means of influence on motivation, stages of introduction of motivational management in educational establishment.

Постановка проблеми. Мета будь-якої управлінської діяльності - організувати роботу таким чином, щоб вона була ефективною. А для цього необхідні ресурси, зокрема матеріальні, фінансові, інформаційні та кадрові. Управління розпочинається з пошуку перших трьох, а також їх раціонального використання. Набагато складнішою є ситуація з кадровими ресурсами. Обираючи для працівників завдання, керівникові насамперед варто замислитися над такими питаннями: «Чи здатен працівник вирішити проблему (чи достатньо у нього знань та вмінь для цього)?»; «Чи має працівник засоби для вирішення проблеми (наприклад, методичні розробки)?»; «Чи хоче працівник вирішити проблему (чи має він бажання зосередити свої зусилля задля іiі вирішення)?». Вітчизняні управлінці та вчені у галузі освіти, як правило, більш грунтовно підходили до аналізу двох перших запитань, на основі чого вибудовували свою управлінську діяльність. Позитивна відповідь на третє запитання вважалася очевидною, передусім, коли йдеться про педагогів. Як відомо, «обличчя школи» визначають професіоналізм учителів (наявність почесних звань, категорій, наукових ступенів чи нагород) та академічні досягнення учнів (кількість переможців олімпіад, медалістів, студентів 3ВО тощо).
Проте варто з'ясувати, чи завжди для успішного розв'язання різноманітних «шкільних» проблем достатньо мати лише висококваліфікованих педагогів.

Працівник будь-якого закладу - це його головний pecyрс. Однак успішна діяльність закладу залежить не лише від професійності та досвідченості його працівників, а й від того, чи хочуть вони працювати, чи вмотивовані вони. Тобто важливо, щоб колектив не лише «вмів», а й «хотів» працювати.

Аналіз наукових досліджень і публікацій. Аналіз теорії та практики управління освітніми організаціями (С. Вершловский, С. Гвірц, П. Гемвелл, Л. Даниленко, Г. Єльникова, І. Зязюн, К. Робінсон, Т. Махиня, В. Мельник, В. Олійник, В. Пекельна, М. Поташник, П. Саух, Т. Сорочан, П. Третьяков, О. Удод, К. Ушаков, Т. Шамова та ін.) засвідчує, що в сучасних умовах керівники 3-поміж усіх типів організаційних ресурсів насамперед роблять наголос на людські ресурси. Це означає, що вдосконалення роботи освітніх установ може бути досягнуто за рахунок кращого їх використання і передбачає цілеспрямовану діяльність управлінців у цьому напрямі, зокрема й щодо мотивації трудової поведінки педагогічного колективу.

Незважаючи на значний ступінь розробленості проблеми мотивації праці у вітчизняних і зарубіжних дослідженнях з управління (А. Альберт, Л. Безтелесна, У. Бреддік, О. Виханський, Ф. Герцберг, Е. Ільїн, С. Каверін, Л. Карамушка, А. Карпов, Р. Кричевський, М. Мескон, Е. Молл, А. Наумов та ін.), керівники установ найчастіше використовують ті прийоми впливу на професійну поведінку педагогів, що призводять до демотивації їх діяльності. Це, наприклад, проявляється у втраті ініціативи та відповідальності, сприйнятті працівниками перебування на робочому місці як простого проведення часу. Таке ставлення працівників до своїх професійних обов'язків може бути пов'язано $з$ недостатньою психологічною компетентністю керівників, недооцінюванням важливості мотивації працівників, а також у зв'язку з відсутністю навичок практичного застосування методів мотивації.

Таким чином, для керівників закладів освіти особливо значимим $є$ вміння переосмислити свій управлінський досвід, подолати власні стереотипні уявлення про мотивацію діяльності педагогічних кадрів, а як наслідок - сформувати в колективі сучасні управлінські взаємовідносини, застосовуючи мотиваційний менеджмент.

Проблематика мотиваційного менеджменту знайшла відображення в працях як українських (А. Колота, В. Сладкевич, С. Цимбалюк), так і російських (Е. Базик, Н. Дрівольска, Н. Кузнецова, Е. Коротков, Л. Лук'янова, М. Мельнікова, В. Травін, Е. Уткін та ін.) науковців, де наявні різні тлумачення сутності, змісту, завдань і функцій мотиваційного менеджменту, які мають бути критично осмислені, систематизовані та доповнені з метою забезпечення впровадження означеної царини знань у практику діяльності вітчизняних закладів освіти.

Мета статті - здійснити критичний аналіз досліджень і публікацій щодо трактування поняття «мотиваційний менеджмент», визначити його об'єкт, предмет та основні етапи запровадження в закладі освіти. 
Виклад основного матеріалу. Термін «мотиваційний менеджмент» в українській науці відносно новий, хоча в зарубіжних дослідженнях він активно використовується вже із середини $90-$-х років ХХ століття. Як не дивно, але в деяких працях, відомих під назвою «Мотиваційний менеджмент», визначення цього поняття або взагалі відсутнє, або автори уникають використання словосполучення «мотиваційний менеджмент» $[1 ; 11 ; 14 ; 15 ; 17]$.

Дехто з авторів, намагаючись визначити сутність терміна «мотиваційний менеджмент», підміняють зовсім іншими поняттями. Так, Н. Кузнєцова у програмі курсу «Мотиваційний менеджмент» (2004) спочатку трактує його як «процес мотивації, тобто активації вже наявних мотивів працівника», а згодом - як «дослідження цих мотивів» [7, с. 21]. Л. Лук'янова у навчально-методичному посібнику «Мотиваційний менеджмент» (2011) зазначає, що «мотивація як мотиваційний менеджмент - це система дій 3 активації мотивів іншої людини» [9, с. 4].

Вітчизняні науковці А. Колот та С. Цимбалюк, автори підручника «Мотиваційний менеджмент» (2014), грунтовно розглядають теоретико-методологічні та прикладні аспекти мотивації працівників, аналізують теорії мотивації та їх вплив на практику управління персоналом, описують сучасні підходи, методи і засоби, за допомогою яких здійснюється активізація трудової діяльності працівників, проте не обгрунтовують сутності поняття «мотиваційний менеджмент», а характеризують його як складову корпоративного менеджменту [13, с. 36], зазначаючи, що «людина є головним ресурсом, найбільшою цінністю і метою розвитку економіки. Першопричини, що зумовлюють підвищення цієї ролі, пов'язані $з$ тим, що людський ресурс (персонал) став носієм найзатребуваніших конкурентних якостей, якими є знання, інтелект, умотивованість, компетентність» [13, с. 28-29]. Отже, можемо припустити, що вищеозначені автори під мотиваційним менеджментом розуміють процес управління людськими ресурсами.
У роботі «Принципи менеджменту: управління в системі цивілізованого підприємництва» (1996) К. Ховард та Е. Коротков трактують мотиваційний менеджмент як «тип управління, в якому пріоритет надається мотивації професійної поведінки, діяльності, відносинам, а не адмініструванню та жорсткому контролю» [19]. Такої ж думки дотримується й Е. Уткін, автор посібника «Основи мотиваційного менеджменту» (2000), зазначаючи, що «одним iз найефективніших видів сучасного управління $є$ мотиваційний менеджмент. Це пояснюється не лише значним підвищенням ролі людського фактора в управлінні, а й тим, що він відображає одну $з$ головних тенденцій розвитку виробництва і суспільства. Тобто, мотиваційний менеджмент - це управління, в якому пріоритет надається мотивації творчої, продуктивної, ініціативної та професійної діяльності людини» [18, с. 110-111].

На нашу думку, мотиваційний менеджмент в освіті - це гнучкий, багаторівневий і багатогранний процес внутрішнього управління діяльністю закладу освіти, вибудуваний на обов'язковому врахуванні вже сформованої чи тієї, що лише має бути сформованою мотивації професійної (як самостійної, так i колективної) поведінки та спільної діяльності всіх працівників завдяки виробленій і сприйнятій колективній зацікавленості в досягненні цілей закладу, дотриманні ціннісних настанов, формуванні та підтримці мотиваційного клімату в закладі. Об'єктом мотиваційного менеджменту є управління процесом формування мотивації всіх працівників закладу освіти задля спільного досягнення мети його діяльності, а предметом мотиваційного менеджменту - психологічні механізми формування мотиваційної сфери працівників, досягнення ними спільної мети і конкретних цілей у їхній професійній діяльності.

Якщо мотиваційний менеджмент - це процес внутрішнього управління діяльністю закладу освіти, то можна виділити основні етапи його запровадження (див. рис.).

\section{Розуміння психологічних закономірностей}

\section{Розуміння принципів трудової мотивації}

\section{Знання закономірностей мотивації праці}

\section{Вибір ефективної мотиваційної моделі}

\section{Знання засобів впливу на професійну мотивацію}


Проаналізуємо кожен етап більш детально.

Перший етап - розуміння психологічних закономірностей, що покладено в основу мотивації праці. При цьому головне в мотивації - iï нерозривний зв'язок із потребами людини. Людина лише в тому випадку самовіддано працюватиме, долаючи перешкоди на шляху до поставленої мети, коли робота і винагорода, яку вона отримає за цю роботу, дозволять ій задовольнити значущі для неї потреби. Зважаючи на це, потреби можна розглядати як причини поведінки, які не лише спонукають до дії, а й впливають на систему цінностей. Цінності представників різних професій, звичайно, є специфічними. Є. Шиянов, наприклад, виділяє особливу групу цінностей, обумовлених працею педагога. До них він відносить: 1) цінності, пов'язані із самоствердженням особистості в соціальному і професійному середовищі (суспільна значущість праці вчителя, престижність педагогічної діяльності, визнання професії найближчим оточенням тощо); 2) цінності, що задовольняють потребу вчителя у спілкуванні (з дітьми, колегами, батьками та ін.; відчуття дитячої любові та прихильності; обмін духовними цінностями); 3) цінності, пов'язані з розвитком творчої індивідуальності (можливість навчатися, самовдосконалюватися, розвивати власні професійно-творчі здібності, долучатися до світової культури, займатися улюбленою справою); 4) цінності, що дозволяють самореалізовуватися (творчість, романтичність, відчуття захоплення професією, прагнення якомога глибше розвинути особистісні риси); 5) цінності, пов'язані із задоволенням утилітарно-прагматичних потреб (отримання достойної заробітної платні, надбавок, наявність відпустки тощо) [20, с. 87-88].

Усі фактори, які впливають на мотиваційний процес й обумовлюють поведінку працівника, називають мотиваційними. Вони складають мотиваційну структуру особистості, що безперервно змінюється під впливом реалій життя, однак зберігає стійкість завдяки системі цінностей, яка регулює способи задоволення потреб.

Другий етап - розуміння ключових принципів, покладених в основу трудової мотивації. До таких принципів (за В. Травіним) відносять: полімотивованість професійної поведінки; ієрархічну організацію мотивів; компенсаторний зв'язок між мотивами; принцип справедливості; принцип підсилення [17, с. 13-20].

Tретій етап - знання закономірностей мотивації праці. Жоден заклад не може досягти успіху без високого рівня прихильності працівників, без їх прагнення докласти максимум зусиль задля досягнення цілей. Саме тому сьогодні неабиякий інтерес керівників i дослідників, які займаються управлінням персоналом, викликають теорії мотивації та їх причини, що змушують людей займатися професійною діяльністю, працювати з повною віддачею сил задля інтересів закладу. За останні два століття було розроблено велику кількість теорій мотивації праці, які мали значний вплив на процес управління. Однак єдиного підходу досі не існує. У зв'язку зі складністю феномена «мотивація» неможливо дати однозначної відповіді на запитання «Що мотивує людей добре працювати?». Цьому є кілька пояснень. По-перше, основне джерело мотивації праці - конкретна ситуація, в якій перебуває конкретний працівник. По-друге, мотивація з часом змінюється $і$ залежить від обставин, в яких перебуває працівник.
По-третє, на організаційну поведінку і роботу працівника можуть впливати одночасно безліч факторів. Знання закономірностей мотивації праці дозволяє керівникам зрозуміти, як краще впливати на працівників, аби вони працювали ефективніше.

Серед найвідоміших підходів до вивчення мотивації праці виділяють: традиційну модель наукового управління Ф. Тейлора; модель «Школа людських стосунків» Е. Мейо та модель «Школа людських ресурсів» Д. Макгрегора. Теоретичні уявлення про трудову мотивацію розглядаються науковцями у трьох напрямах: змістовні теорії, в основу яких покладено потреби, індивідуальні цілі та прагнення людей (А. Маслоу, К. Альдерфер, Ф. Герцберг, Дж. Аткінсон, Д. Мак Клелланд); процесні теорї, що грунтуються на механізмах мотиваційних процесів та проявляються в розумінні робочої ситуації, прийнятті рішень і робочої поведінки (Дж. Адамс, В. Врум, Л. Портер, Е. Лоулер, Е. Локк); теорія підкріплення, основний акцент в якій зроблено на тому, як люди освоюють ті чи інші види поведінки і яким чином їх можна спонукати до бажаної поведінки (Б. Скіннер). При цьому варто зауважити, що всі без винятку теорії перебувають у постійному розвитку, тобто керівник-практик може почерпнути із кожної із них щось корисне, відкидаючи при цьому будь-який негатив.

Четвертий етап - вибір ефективної мотиваційної моделі. Найвідомішими є три мотиваційні моделі: 1) раціональна - в її основу покладено використання матеріальних і моральних стимулів; 2) самореалізації - ії суть полягає в активізації внутрішніх мотивів людини; 3) співучасті - реалізується через розвиток співробітництва, партнерства, співучасті в управлінні закладом (організацією) та делегуванні [10, 74-112].

П'ятий етап - знання засобів впливу на професійну мотивацію. Успішний вплив на мотивацію працівників можливий лише за наявності комплексного підходу, коли керівник використовує різноманітні засоби, враховуючи не лише ситуацію, а й особистісні характеристики працівників. Зокрема, В. Травін серед засобів впливу на мотивацію виділяє: організацію праці; матеріальне та моральне стимулювання; постановку цілей; оцінку і контроль; інформування; практику управління; заходи дисциплінарного стягнення; звернення до значимих для працівника цінностей [17, с. 65].

Шостий етап - розробка системи мотивації професійної поведінки працівників, що вважається пріоритетним завданням сучасного управлінця, від успішного розв'язання якого залежить ефективність діяльності очолюваного ним закладу освіти. Незважаючи на важливість такої системи, більшість керівників якщо і впроваджують певні мотиваційні інструменти, то роблять це хаотично й безсистемно. Нами було визначено сім важливих кроків розробки ефективної системи мотивації персоналу: 1) з'ясування проблем, що існують у закладі у зв'язку з відсутністю системи мотивації працівників та їх причини; 2) визначення ключових завдань системи мотивації працівників; 3) проведення соціологічного дослідження 3 метою з'ясування ефективних мотиваційних факторів для колективу загалом і кожного працівника зокрема; 4) розробка коротко-, середньо- та довгострокової програми мотивації персоналу в закладі освіти; 5) розрахунок матеріальних затрат на впровадження оптимальної програми мотиваційних заходів; 
6) інформування працівників про нововведення, вимоги, цілі та завдання, що ставляться перед ними; 7) запровадження та тестування мотиваційної системи, а після завершення короткострокової програми мотиваційних заходів - розрахунок корисності означених заходів [10, с. 137-147].

Висновки. Таким чином, нами було з'ясовано, що для успішного досягнення цілей освітніх установ необхідні не лише різноманітні матеріальні ресурси і підготовлений персонал, а й прагнення педагогів працювати ефективно, що залежить від їхньої професійної мотивації. Рівень мотивації визначає особливості сприйняття вчителем учнів, підсвідому роль педагога в класі, впливає на характер взаємин між усіма учасниками освітнього процесу, що у підсумку визначає його ефективність.

Виконання дій щодо мотивації праці - справа нелегка. Швидкі зміни в економічній, політичній та соціальній сферах, що притаманні сучасному суспільству, впливають і на мотиваційну сферу педагогів, змінюючи ієрархію традиційно значимих для вчителів потреб. Ця сфера надзвичайно динамічна, а тому деяким керівникам інколи важко ії осягнути. Усе це вимагає регулярного звернення до аналізу поведінки вчителів із метою виявлення найбільш значимих для них мотивів праці.

Крім того, нами було доведено, що особливість управління сучасними освітніми організаціями полягає в тому, що воно включає дві складові: управління освітнім процесом та управління людьми як учасниками цього процесу. При цьому успішне управління першою складовою неможливо уявити без управління персоналом закладу освіти. Таким чином, уміння спонукати працівників досягати цілей закладу стає одним із визначальних умінь сучасного керівника, яке може бути сформоване завдяки застосуванню мотиваційного менеджменту.

На нашу думку, мотиваційний менеджмент - це гнучкий, багаторівневий i багатогранний процес внутрішнього управління діяльністю закладу освіти, вибудуваний на обов'язковому врахуванні вже сформованої чи тієї, що лише має бути сформованою мотивації професійної (як самостійної, так і колективної) поведінки та спільної діяльності всіх працівників завдяки виробленій і сприйнятій колективній зацікавленості в досягненні цілей закладу, дотриманні ціннісних настанов, формуванні та підтримці мотиваційного клімату в закладі.

Опираючись на підходи до реалізації функції мотивації [2; 4-6], сутність мотиваційного процесу [18], концепцію мотиваційного менеджменту [18], зміст мотиваційних програм $[6 ; 12]$, нами було окреслено шість етапів упровадження мотиваційного менеджменту в закладі освіти.

\section{СПИСОК ВИКОРИСТАНОЇ ЛІТЕРАТУРИ}

1. Базык Е. Ф. Теория и практика применения системы мотивационного менеджмента / Е. Ф. Базык // Актуальные проблемы гуманитарных и естественных наук. - 2014. - № 8-1. - С. 95-107.

2. Бакурадзе А. Мотивация труда педагогов / А. Бакурадзе. - М., 2005. - Сентябрь. - 192 с.

3. Дривольская Н. Мотивационный менеджмент как инструмент управления персоналом предприятия /
H. Дривольская. URL: https:/cyberleninka.ru/article/n/ motivatsionnyy-menedzhment-kak-instrument-upravleniya-personalom-predpriyatiya (дата звернення: 15.11.2019).

4. Виханский О. С. Менеджмент : учебник / О. С. Виханский, А. И. Наумов. - Изд. 4-е, перераб. и доп. - М. : Экономистъ, 2006. - 670 с.

5. Карамушка Л. М. Психологія управління : навч. посіб. / Л. М. Карамушка. - К. : Міленіум, 2003. $344 \mathrm{c}$.

6. Карпов А. В. Психология менеджмента : учеб. Пособие / А. В. Карпов. - М. : Гардарики, 2005. - 584 c. URL: http://sbiblio.com/biblio/archive/karpov_psiho. 6 (дата звернення: 20.11.2019).

7. Кузнецова Н. В. Мотивационный менеджмент / H. В. Кузнецова. URL: http://www.twirpx.com/ file/88145/. 29.12 (дата звернення: 05.12.2019).

8. Кузьмін О. С. Основи менеджменту / О. Є. Кузьмін, О. Г. Мельник. - К. : Академвидав, 2003. -414 c.

9. Лукьянова Л. Б. Мотивационный менеджмент : учебное пособие / Н. А. Лукьянова - Томск : Изд-во Томского политехн. ун-та, 2011. - 106 с.

10. Лютко О. М. Запровадження мотиваційного менеджменту в закладі освіти / О. М. Лютко. - Рівне : РОІППО, 2018. - 180 с.

11. Мельникова М. Н. Мотивационный менеджмент / М. Н. Мельникова. - Хабаровск : Издательство ДВГУПС, 2001. -81 с.

12. Молл Е. Г. Менеджмент. Организационное поведение : учебное пособие по специальности «Менеджмент» / Е. Г. Молл. - М. : Финансы и статистика, 1999. $-160 \mathrm{c}$.

13. Мотиваційний менеджмент : підручник / А. М. Колот, С. О. Цимбалюк. - К. : КНЕУ, 2014. $479 \mathrm{c}$.

14. Сладкевич В. П. Мотивационный менеджмент: курс лекций / В. П. Сладкевич. - К. : МАУП, 2001. -168 c.

15. Старобинский Э. Е. Как управлять персоналом : учеб.-практ. пособие / Э. Е. Старобинский. Изд. 6-е, перераб. и доп. - М. : Интел-Синтез, 2013. $384 \mathrm{c}$.

16. Соченко В. М. Сучасна філософія мотиваційного менеджменту / В. M. Соченко. URL: http:// business-navigator.ks.ua/journals/2012/29_2012/34.pdf. (дата звернення: 19.12.2019).

17. Травин В. В. Мотивационный менеджмент. Модуль III: учеб.-практ. пособ. / В. В. Травин, М. И. Магура, М. Б. Курбатова. - Изд. 2-е, испр. - М. : Дело, 2005. - 96 с.

18. Уткин Э. А. Основы мотивационного менеджмента / Э. А. Уткин. - М. : Ассоциация авторов и издателей «ТАНДЕМ». Издательство ЭКМОС, 2000. $352 \mathrm{c.}$

19. Хокард К. Принципы менеджмента: управление в системе цивилизованного предпринимательства : учеб. пособие / К. Ховард, Э. Коротков. URL: https://stud.com.ua/58307/menedzhment/menedzhment (дата звернення: 31.12.2019).

20. Шиянов Е. Н. Гуманизация педагогического образования: состояние и перспективы / Е. Н. Шиянов. - Ставрополь : СГПИ, 1991. - 205 с.

Дата надходження до редакиї: 03.01.2020 p. 